\title{
Aplikasi Model Predictive Control (MPC) Pada Optimasi Portofolio Komoditas
}

\author{
Wawan Hafid Syaifudin ${ }^{1}$, Ulil Azmi ${ }^{2}$ \\ 1,2Departemen Aktuaria, Fakultas Sains dan Analitika Data, Institut Teknologi Sepuluh Nopember, Indonesia, \\ ${ }^{1}$ wawan.hafid@gmail.com, ${ }^{2}$ ulilazmi0211@gmail.com \\ DOI 10.30812/varian.v3i2.646
}

\section{INFO ARTIKEL}

\section{Riwayat Artikel:}

Diterima: 27-02-2020

Disetujui: 21-03-2020

\section{Kata Kunci:}

Manajemen Portofolio

Komoditas

Model Predictive Control

(MPC)

Optimasi Portofolio

Komoditas.

\section{ABSTRAK}

Abstrak: Komoditas merupakan salah satu jenis investasi yang disediakan oleh pasar modal kepada investor. Dalam investasi komoditas, terdapat dua hal yang menjadi pertimbangan investor, yaitu return dan risiko. Tujuan utama dalam investasi komoditas adalah memaksimalkan return dengan tingkat risiko tertentu atau meminimalkan risiko dengan tingkat return tertentu. Penentuan portofolio komoditas yang optimal merupakan salah satu hal yang sangat penting bagi kalangan investor. Pada penelitian ini digunakan metode pengendali Model Predictive Control (MPC) untuk menyelesaikan permasalahan optimasi portofolio komoditas dengan adanya kendala didalam pembentukan portofolio. Data yang digunakan adalah data 3 komoditas yang diperdagangkan meliputi emas, tembaga, dan minyak. Pengendali MPC dapat diterapkan dengan baik pada permasalahan optimasi portofolio komoditas. Dari hasil simulasi terlihat bahwa jumlah modal yang dimiliki investor yang merupakan output dari sistem menunjukkan peningkatan yang signifikan. Kenaikan ini terjadi karena jumlah modal yang diinvestasikan pada portofolio komoditas berusaha untuk mencapai reference trajectory yang ditetapkan. Selain itu state dan input dari sistem selalu berada di dalam batas constraint yang diberikan.

Abstract: Commodity is one type of investment provided by financial market for investor. With regards to commodities investment, there are two main issues that should be considered by the investor, namely return and risk. The main objective in this investment is to maximize the return on a certain level of risk, or to minimize the risk on a certain rate of return. The determination of an optimal commodity portfolio is an important issue for investors. Therefore, in this study, we proposed Model Predictive Control (MPC) to solve the optimization problem of commodity portfolio. The data of three major traded commodities, namely gold, copper, and oil were used in the simulation. Based on the simulation results, the MPC method successfully solved the optimization problem on the commodities portfolio by maximizing the return and increasing the amount of investor's capital. This increase was affected by the setting up of reference trajectory on the output of system. It was also noticeable that MPC method had successfully maintained all the control and state variables within the constraints. 


\section{A. LATAR BELAKANG}

Investasi merupakan salah satu kegiatan bisnis yang dapat dilakukan oleh masyarakat dengan tujuan untuk menambah jumlah kekayaan atau modal yang dimiliki. Dalam hal ini, pasar modal menyediakan berbagai alternatif pilihan kepada masyarakat untuk berinvestasi. Salah satu jenis instrumen investasi finansial yang paling populer di kalangan investor adalah komoditas. Pada umumnya, investor menanamkan modal dengan cara membeli komoditas melalui perantara pasar modal. Dalam beberapa tahun terakhir, kegiatan transaksi perdagangan komoditas di pasar modal semakin berkembang seiring dengan meningkatnya keinginan masyarakat bisnis untuk mencari alternatif sumber pembiayaan usaha selain bank (Darmadji \& Fakhruddin, 2011).

Selain itu, meningkatnya keinginan masyarakat untuk menjadi investor juga turut mempengaruhi perkembangan pasar modal. Hal ini dapat dilihat dari dalam kurun waktu beberapa tahun terakhir indeks harga komoditas gabungan (IHSG) mengalami peningkatan. Sebagai contoh, pada akhir tahun 2015, indeks harga komoditas gabungan ditutup pada posisi 4.593,01 poin. Nilai ini kemudian naik pada akhir tahun 2016 yang mencapai $5.296,71$ poin dan naik secara signifikan pada akhir tahun 2017 pada posisi $6.355,65$ poin (Widianto, 2017).

Dalam investasi komoditas, terdapat dua hal utama yang menjadi pertimbangan investor dalam memilih jenis komoditas yang akan dibeli yaitu tingkat pengembalian (return) dan tingkat risiko (Bodie et al, 2015). Seorang investor diharapkan memiliki kemampuan untuk dapat memilih komoditas secara rasional. Rasionalitas investor dapat diukur berdasarkan cara dalam memilih komoditas yang memberikan return maksimum pada tingkat risiko tertentu atau mempunyai risiko minimum pada tingkat return tertentu (Chandra, 2017). Langkah pendekatan yang dapat dilakukan oleh para investor adalah dengan melakukan penghitungan dalam pemilihan dan penentuan portofolio serta pola perilaku investor lainnya di bursa efek dalam transaksi jual beli komoditas. Cara seperti ini disebut sebagai strategi investasi aktif (Martinsuo \& Lehtonen, 2007). Sebagai langkah untuk mengurangi risiko yang akan ditanggung dalam investasi komoditas, investor secara umum akan melakukan proses diversifikasi atau penyebaran investasi pada beberapa perusahaan dengan membentuk suatu kelompok aset yang disebut dengan portofolio komoditas (Levine, 2005).

Salah satu hal yang harus dimiliki oleh investor dalam menentukan keberhasilan investasi di bidang komoditas adalah kemampuan untuk mengelola portofolio komoditas atau disebut dengan manajemen portofolio komoditas. Dalam hal ini, investor dituntut untuk memiliki pengetahuan mengenai cara menentukan portofolio komoditas yang optimal sehingga dapat menghasilkan return yang maksimal dengan tingkat risiko yang dapat dipertanggungjawabkan.

Pada dasarnya, dalam manajemen portofolio komoditas terdapat permasalahan kendali yang berkaitan dengan cara untuk mengoptimasi portofolio komoditas dari investor agar mendapatkan return yang optimal, sehingga dapat meningkatkan modal yang dimiliki investor setelah melakukan investasi (Bodie et al, 2015). Permasalahan optimasi portofolio komoditas pada dasarnya merupakan permasalahan dinamis yang melibatkan dinamika stokastik dari harga aset yang terus berkembang. Selain itu, terdapat beberapa permasalahan kontrol didalam alokasi portofolio yang digunakan untuk mengontrol modal dari investor. Beberapa kendala yang megikutinya antara lain pembagian alokasi dana yang terbatas dan batasan jumlah pinjaman yang diperkenankan. Oleh karena itu diperlukan adanya peran kendali optimal dalam optimasi portoflio komoditas.

Salah satu metode kontrol yang dapat digunakan dalam mengatasi kendala pada permasalahan ini adalah model predictive control (MPC). Tipe pengendali ini termasuk dalam kategori pengendali berbasis model proses, yaitu model proses digunakan secara eksplisit untuk mendesain pengendali, dengan meminimumkan suatu fungsi kriteria. Selain itu, MPC dapat menggabungkan semua tujuan menjadi fungsi 
objektif tunggal serta optimasi yang diberikan sangat efektifuntuk menanganisistemyang memiliki kendala pada input dan state (Alba \& Camacho, 2013).

MPC banyak digunakan dalam bidang industri. Salah satu alasan utama keberhasilan MPC pada aplikasi dalam bidang industri adalah kemampuan dalam menerapkan berbagai jenis kendala pada proses (Qin \& Badgwell, 2003). Penelitian mengenai aplikasi dari model predictive control (MPC) telah banyak dilakukan pada berbagai bidang keilmuan. Salah satunya adalah penerapan MPC pada kendali haluan kapal (Subchan et al, 2014). Pada penelitian tersebut, pengendali MPC dapat diterapkan dengan baik pada kendali haluan kapal, dimana state dan input dari sistem berada dalam batas constraint yang diberikan dan gerakan dari kapal dapat mengikuti reference trajectory yang diinginkan, baik pada sistem tanpa gangguan maupun pada sistem dengan gangguan.

Penelitian lain yang berkaitan dengan penerapan MPC dilakukan oleh Yuninda, yaitu pengendalian kadar glukosa penderita diabetes mellitus tipe 1 berbasis metode aktif set MPC (Yuninda, 2008). Pada bidang industri, metode MPC diterapkan pada proses industri kimia, yaitu pada reaktor polimerisasi (Seki et al, 2001). Berdasarkan kajian penelitian-penelitian sebelumnya tersebut, maka dalam penelitian ini diajukan penerapan model predictive control (MPC) pada optimasi portofolio komoditas agar didapatkan portofolio komoditas yang optimal.

\section{B. TINJAUAN PUSTAKA}

Investasi pada aset finansial merupakan penempatan sejumlah dana pada kontrak finansial dengan harapan untuk memperoleh keuntungan di masa mendatang. Ketika portofolio komoditas dipilih, hal utama yang perlu diperhatikan adalah mekanisme atau aturan dalam manajemen portofolio komoditas tersebut.

Pada awal waktu, seorang investor memiliki sejumlah modal yang dapat digunakan untuk berinvestasi pada $i$ aset, dengan $i=1,2, \ldots, n$. Secara umum modal yang dimaksud dalam hal ini adalah uang yang dimiliki oleh investor yang diinvestasikan pada komoditas ke- $i$.

Selain itu, kekayaan investor juga berasal dari aset bebas risiko, yaitu aset yang terdapat di bank yang menghasilkan yield. Aset investor yang terdapat di bank selanjutnya disebut aset ke- $n+1$. Seorang investor harus memutuskan bagaimana cara untuk mengatur ulang portofolio komoditasnya setiap hari dengan tujuan untuk mendapatkan return yang maksimal pada investasinya.

Model manajemen portofolio untuk $n$ aset dapat dituliskan sebagai berikut (Dombrovsky \& Lashenko, 2003):

$$
x_{i}(k+1)=\left[1+\eta_{i}(k)\right]\left[x_{i}(k)+p_{i}(k)-q_{i}(k)\right], \quad i=1,2, \ldots, n
$$

dengan

$\eta_{i}(k) \quad$ : return dari aset ke- $i$

$p_{i}(k)$ : jumlah transfer dari aset bebas risiko ke aset berisiko ke- $i$

$q_{i}(k) \quad$ : jumlah transfer dari aset berisiko ke-i ke aset bebas risiko

$x_{i}(k) \quad$ : jumlah modal yang diinvestasikan oleh investor pada aset berisiko ke- $i$

$p_{i}(k)>0$ dan $q_{i}(k)>0$. 
Biaya transaksi yang dibayarkan didefinisikan sebagai $\alpha$ dan $\beta$, masing-masing menunjukkan biaya transaksi dalam pembelian dan biaya transaksi dalam penjualan komoditas. Persamaan (2) berikut ini menunjukkan perubahan dari aset bebas risiko.

$$
x_{n+1}(k+1)=\left[1+r_{1}(k)\right]\left[x_{n+1}(k)-(1-\alpha) \quad \sum_{i=1}^{n} p_{i}(k)+(1-\beta) \sum_{i=1}^{n} q_{i}(k)\right.
$$

dengan

$r_{1}(k)$ : tingkat suku bunga bank

Berdasarkan penjelasan yang telah diuraikan di atas, jumlah seluruh modal dari seorang investor dalam portofolio komoditas dapat dituliskan sebagai berikut (Dombrovsky \& Lashenko, 2003):

$$
V(k)=\sum_{i=1}^{n+1} x_{i}(k)
$$

Seperti yang terlihat pada persamaan (3), jumlah modal dari investor merupakan penjumlahan dari kekayaan investor pada aset-aset berisiko serta aset bebas risiko yang dimiliki oleh investor dan dikurangi dengan pinjaman modal.

Pada pemodelan matematika dari manajemen portofolio komoditas, didefinisikan variabel state sistem adalah $\tilde{\mathbf{x}}$, yang meliputi $x_{1}, \ldots, x_{n}, x_{n+1}$, dan $x_{n+2}$. Variabel $x_{1}, \ldots, x_{n}$ menunjukkan jumlah modal yang diinvestasikan oleh investor pada aset berisiko (komoditas) ke-1 sampai dengan ke- $n$. Sedangkan variabel $x_{n+1}$ menunjukkan jumlah modal investor pada aset bebas risiko (bank).

Variabel kontrol didefinisikan sebagai $\widetilde{\mathbf{u}}$ yang meliputi $p_{i}, q_{i}$ dan $v$, dengan $i=1,2, \ldots, n$. Variabel output sistem didefinisikan sebagai $\tilde{\mathbf{y}}$ yang merupakan jumlah seluruh modal yang dimiliki oleh investor.

Berdasarkan keterangan tersebut, serta dengan menggunakan persamaan (1) sampai dengan persamaan (3), maka dapat dibentuk persamaan ruang keadaan diskrit sebagai berikut (Wang, 2009):

$$
\begin{gathered}
\widetilde{\boldsymbol{x}}(k+1)=\mathbf{A} \tilde{\mathbf{x}}(k)+\mathbf{B} \widetilde{\mathbf{u}}(k) \\
\widetilde{\boldsymbol{y}}(k)=\mathbf{C} \tilde{\mathbf{x}}(k)
\end{gathered}
$$

dengan

$$
\widetilde{\mathbf{x}}(k+1)=\left[\begin{array}{c}
x_{1}(k+1) \\
\vdots \\
x_{n}(k+1) \\
x_{n+1}(k+1)
\end{array}\right], \quad \widetilde{\mathbf{u}}(k)=\left[\begin{array}{c}
p_{1}(k) \\
\vdots \\
p_{n}(k) \\
q_{1}(k) \\
\vdots \\
q_{n}(k)
\end{array}\right], \quad \mathbf{A}=\left[\begin{array}{cccc}
1+\eta_{1}(k) & \cdots & 0 & 0 \\
\vdots & \ddots & \vdots & \vdots \\
0 & \cdots & 1+\eta_{i}(k) & 0 \\
0 & \cdots & 0 & 1+r_{1}(k)
\end{array}\right]
$$

$\mathbf{C}=[1 \cdots 1]$

Pada permasalahan optimasi portofolio komoditas didefinisikan beberapa kendala sebagai berikut (Dombrovsky \& Lashenko, 2003):

$$
\begin{aligned}
& 0 \leq p_{i}(k) \leq p_{i}(\max ), \text { dengan } i=1,2, \ldots, n \\
& 0 \leq q_{i}(k) \leq q_{i}(\max ), \text { dengan } i=1,2, \ldots, n
\end{aligned}
$$


Selain itu, variabel state $x_{n+1}$ yang merupakan jumlah modal yang dimiliki oleh investor di bank tidak mungkin bernilai negatif, sehingga didefinisikan kendala untuk variabel state $x_{n+1}$ adalah sebagai berikut:

$$
x_{n+1}(k)-(1+\alpha) \sum_{i=1}^{n} p_{i}(k)+(1-\beta) \sum_{i=1}^{n} q_{i}(k) \quad \geq 0
$$

Pada perdagangan komoditas dikenal pula istilah short selling yang merupakan suatu cara yang digunakan dalam penjualan komoditas dimana para investor meminjam dana untuk menjual komoditas (yang belum dimiliki) dengan harga tinggi dan investor akan membelinya kembali saat harga komoditas turun. Namun dalam penelitian ini, short selling tidak diperkenankan, sehingga didefinisikan kendala pada short selling sebagai berikut:

$$
x_{i}(k)+p_{i}(k)-q_{i}(k) \geq 0
$$

Dalam MPC persamaan yang digunakan adalah persamaan dalam bentuk matriks ruang keadaan diskrit dan linier. Persamaan ruang keadaan diskrit yang digunakan adalah sebagai berikut (Wang, 2009):

$$
\begin{aligned}
\tilde{\mathbf{x}}(k+1 \mid k) & =\mathbf{A} \tilde{\mathbf{x}}(k \mid k)+\mathbf{B} \widetilde{\mathbf{u}}(k \mid k) \\
\tilde{\mathbf{y}}(k \mid k) & =\mathbf{C} \tilde{\mathbf{x}}(k \mid k)
\end{aligned}
$$

dengan:

$\tilde{\mathbf{x}}(k \mid k)$ : vektor ruang keadaan berdimensi- $n$

$\tilde{\mathbf{y}}(k \mid k)$ : vektor keluaran terukur berdimensi- $n$

$\widetilde{\mathbf{u}}(k \mid k)$ : vektor masukan berdimensi- $m$

A : matriks keadaan berdimensi $n \times n$

B : matriks masukan berdimensi $n \times m$

C : matriks keluaran berdimensi $n \times n$

$\boldsymbol{a}(m \mid n)$ : nilai $\boldsymbol{a}$ saat $m$ yang diprediksi ketika berada dalam tahap $n$.

Pada MPC, proses pengendalian dilakukan secara prediktif. Metode pengendali optimal yang digunakan pada MPC linear ini adalah quadratic programming (QP). Karena dalam penelitian ini sistem bekerja dalam kondisi waktu diskrit maka didefinisikan fungsi objektif (Wang \& Boyd, 2009):

$$
J(\widetilde{\mathbf{u}}(k), \widetilde{\mathbf{e}}(k))=\sum_{t=1}^{N_{p}} \widetilde{\mathbf{e}}(k+j)^{T} \mathbf{Q} \widetilde{\mathbf{e}}(k+j)+\widetilde{\mathbf{u}}(k+j)^{T} \mathbf{R} \widetilde{\mathbf{u}}(k+j)
$$

dengan $\tilde{\mathbf{e}}(k+j)=\tilde{\mathbf{y}}(k)-\mathbf{r}(k)$, serta $\mathbf{r}(k)$ dan $N_{p}$ masing-masing menunjukkan reference trajectory dan prediction horizon.

Selain itu, $\widetilde{\mathbf{u}}(k+j)$ menunjukkan kontrol dari sistem pada saat langkah ke- $k+j$, sedangkan $\widetilde{\mathbf{e}}(k+j)$ adalah eror saat langkah waktu ke- $k+j$. Matriks $\mathbf{Q}$ dan $\mathbf{R}$ masing-masing merupakan matriks bobot semi definit positif yang berkaitan dengan $\widetilde{\mathbf{e}}$ dan $\widetilde{\mathbf{u}}$. 
Tujuan dari MPC adalah mendapat kontrol optimal $\widetilde{\mathbf{u}}^{*}$ yang akan meminimalkan nilai dari fungsi objektif. Karena kontrol optimal dalam MPC memiliki bentuk quadratic programming (QP), maka kita dapat menuliskan kembali fungsi objektif pada persamaan (12) sebagai berikut (Muske \& Rawlings, 1993):

$$
\min J(\widehat{\mathbf{u}}(k))=\widehat{\mathbf{u}}^{T}(k) \mathbf{H} \widehat{\mathbf{u}}(k)+2 \mathbf{f}^{T} \widehat{\mathbf{u}}(k)
$$

dengan

$\mathbf{H}=\left(\widehat{\mathbf{B}}^{\mathbf{T}} \widehat{\mathbf{Q}} \widehat{\boldsymbol{B}}+\widehat{\boldsymbol{R}}\right)$

$\mathbf{f}=\widehat{\mathbf{B}}^{\mathbf{T}} \widehat{\mathbf{Q}}(\widehat{\mathbf{A}} \mathbf{x}(k)-\mathbf{r}(k))$

$\widehat{\mathbf{u}}(k)=\left[\widetilde{\mathbf{u}}(k), \widetilde{\mathbf{u}}(k+1), \ldots, \widetilde{\mathbf{u}}\left(k+N_{p}-\mathbf{1}\right)\right]^{T}$

$\widehat{\mathbf{B}}=\left[\begin{array}{cccccc}\mathbf{C B} & 0 & 0 & 0 & \cdots & 0 \\ \mathbf{C A B} & \mathbf{C B} & 0 & 0 & \cdots & 0 \\ \mathbf{C A}^{\mathbf{2}} \mathbf{B} & \mathbf{C A B} & \mathbf{C B} & 0 & \cdots & 0 \\ \mathbf{C A}^{\mathbf{3}} \mathbf{B} & \mathbf{C A}^{\mathbf{2}} \mathbf{B} & \mathbf{C A B} & \mathbf{C B} & \cdots & 0 \\ \vdots & \vdots & \vdots & \vdots & \ddots & \vdots \\ \mathbf{C A}^{\mathbf{N}} \mathbf{- 1} \mathbf{B} & \mathbf{C A}^{\mathbf{N}_{\mathbf{P}}-\mathbf{B}} \mathbf{B} & \mathbf{C A}^{\mathbf{N}-3} \mathbf{B} & \mathbf{C A}^{\mathbf{N}_{\mathbf{P}}-\mathbf{4}} \mathbf{B} & \cdots & \mathbf{C B}\end{array}\right]_{N_{p} \times N_{p}}$

$\widehat{\mathbf{A}}=\left[\begin{array}{c}\mathbf{C} \\ \mathbf{C A} \\ \mathbf{C A}^{2} \\ \vdots \\ \mathbf{C A}^{\mathrm{N}_{\mathrm{p}}-1}\end{array}\right]_{N_{p} \times 1}, \widehat{\mathbf{Q}}=\left[\begin{array}{ccccc}\mathbf{Q} & 0 & 0 & \cdots & 0 \\ 0 & \mathbf{Q} & 0 & \cdots & 0 \\ 0 & 0 & \mathbf{Q} & \cdots & 0 \\ \vdots & \vdots & \vdots & \ddots & \vdots \\ 0 & 0 & 0 & \cdots & \mathbf{Q}\end{array}\right]_{N_{p} \times N_{p}}, \widehat{\mathbf{R}}=\left[\begin{array}{ccccc}\mathbf{R} & 0 & 0 & \cdots & 0 \\ 0 & \mathbf{R} & 0 & \cdots & 0 \\ 0 & 0 & \mathbf{R} & \cdots & 0 \\ \vdots & \vdots & \vdots & \ddots & \vdots \\ 0 & 0 & 0 & \cdots & \mathbf{R}\end{array}\right]_{N_{p} \times N_{p}}$

Nilai kontrol optimal sistem pada waktu ke-k:

$$
\widehat{\mathbf{u}}^{*}(k)=\left[\widetilde{\mathbf{u}}^{*}(k), \widetilde{\mathbf{u}}^{*}(k+1), \ldots, \widetilde{\mathbf{u}}^{*}\left(k+N_{p}-\mathbf{1}\right)\right]^{T}
$$

Dengan menggunakan prinsip receding horizon pada MPC, yakni nilai kontrol optimal yang diinputkan pada sistem adalah vektor awal dari penyelesaian optimalnya, maka nilai kontrol yang diberikan pada sistem adalah:

$$
\widetilde{\mathbf{u}}(k \mid k)=\widetilde{\mathbf{u}}^{*}(k)
$$

\section{METODE PENELITIAN}

Pada penelitian ini, data yang digunakan adalah data harga 3 jenis komoditas sekunder meliputi komoditas emas, tembaga, dan minyak yang secara berturut-turut disebut sebagai komoditas ke-1, komoditas ke-2, dan komoditas ke-3. Pada tahap inisiasi awal, didefiniskan nilai kontrol awal dari sistem adalah 0 . Hal ini berarti bahwa $p_{i}=q_{i}=0$, di mana $i=1,2,3$. Selain itu, diberikan nilai state awal

$$
\begin{aligned}
\tilde{\mathbf{x}}(0) & =\left[\mathrm{x}_{1}(0), \mathrm{x}_{2}(0), \mathrm{x}_{3}(0), \mathrm{x}_{4}(0)\right]^{T} \\
& =\left[0,0,0,1 \times 10^{5}\right]^{T}
\end{aligned}
$$


Variabel $\mathrm{x}_{1}, \mathrm{x}_{2}$, dan $\mathrm{x}_{3}$ masing-masing menunjukkan jumlah modal yang diinvestasikan pada komoditas emas, tembaga, dan minyak. Pada kondisi awal seluruh modal yang dimiliki oleh investor diinvestasikan ke dalam aset bebas risiko (bank). Oleh karena itu, jumlah modal awal pada aset berisiko adalah 0 .

Seluruh parameter yang digunakan pada simulasi numerik ini dapat dilihat pada Tabel 1. Sebagai catatan, parameter $\alpha, \beta, r_{1}$, and $r_{2}$ didapatkan dari salah satu bank swasta di Asia Tenggara, sedangkan parameter lainnya dipilih oleh penulis.

Tabel 1. Parameter yang Digunakan Pada Simulasi Numerik

\begin{tabular}{|c|c|}
\hline Variabel & Nilai \\
\hline$\alpha$ & 0,0002 \\
\hline$\beta$ & 0,0002 \\
\hline$r_{1}$ & 0,00031 \\
\hline$r_{2}$ & 1003 \\
\hline$\tilde{\mathbf{x}}(0)$ & $\left.0,1 \times 10^{5}\right]^{T}$ \\
\hline$N_{p}$ & 1 \\
\hline$Q$ & 0,1 \\
\hline$R$ & $1 \times 10^{6}$ \\
\hline$r(k)$ & $1 \times 10^{5}$ \\
\hline$p_{i}(\max )$ & $1 \times 10^{5}$ \\
\hline$q_{i}(\max )$ & \\
\hline
\end{tabular}

\section{HASIL DAN PEMBAHASAN}

Dari hasil analisis pengendali MPC yang telah dijelaskan, selanjutnya akan disimulasikan pada bagian ini dengan menggunakan software Matlab.

Tujuan dari optimasi portofolio komoditas dengan menggunakan metode MPC adalah membuat output dari sistem, dalam hal ini merupakan total seluruh modal yang dimiliki oleh investor, terus bertambah setiap harinya dengan mengikuti reference trajectory yang ditetapkan serta menjaga kontrol dan state dari sistem agar tetap berada dalam batas constraint yang ditetapkan. Hasil simulasi pada kontrol dari sistem dapat dilihat pada Gambar 1.

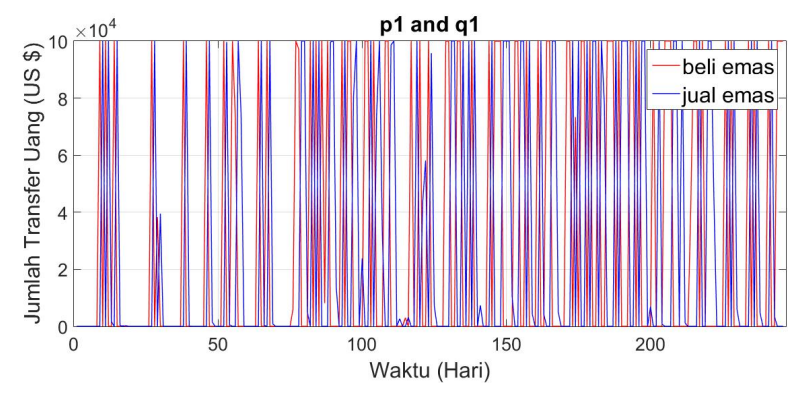

(a) 


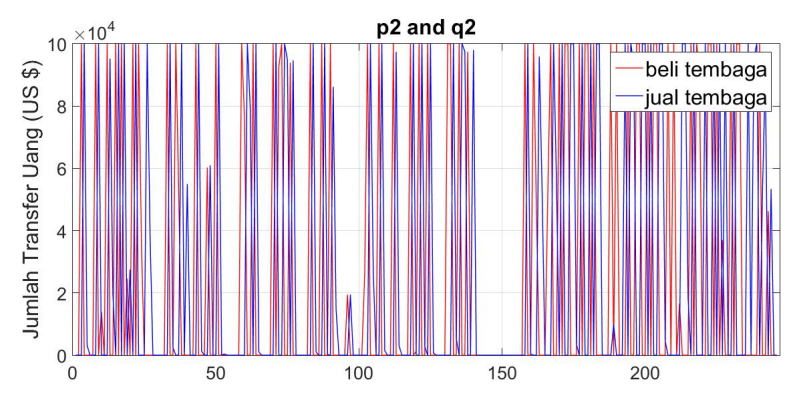

(b)

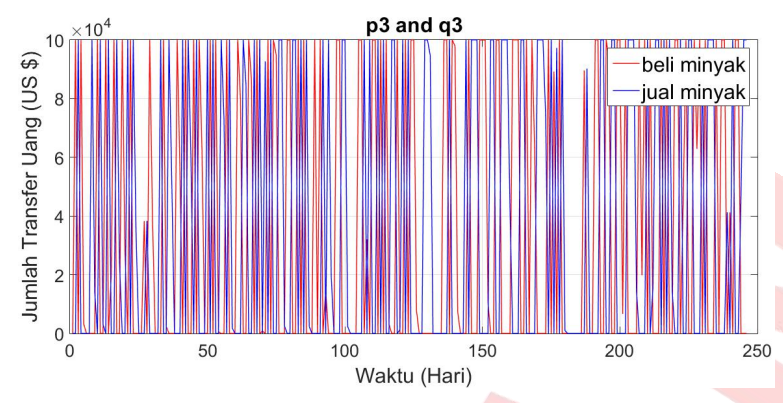

(c)

Gambar 1. Variabel Kontrol Pada Optimasi Portofolio Komoditas: (a) $p$ dan $q$ pada Emas, (b) $p$ dan $q$ pada Tembaga, (c) $p$ dan $q$ pada Minyak

Berdasarkan Gambar 1(a)-1(c) diketahui bahwa nilai seluruh kontrol dari sistem berada dalam batas constraint yang diberikan. Seluruh nilai $p_{1}(k), p_{2}(k), p_{3}(k), q_{1}(k), q_{2}(k)$ dan $q_{3}(k)$ berada diantara nilai minimumnya yaitu 0 , dan nilai maksimumnya yaitu $10^{5}$. Nilai reference trajectory yang besar menyebabkan kontrol dari sistem selalu berusaha mencapai nilai maksimumnya.

Berikutnya, Gambar 2 berikut ini menunjukkan perubahan modal yang dimiliki oleh investor pada masing-masing komoditas. Berdasarkan Gambar 2, terlihat bahwa nilai return harian berpengaruh terhadap jumlah modal yang diinvetasikan pada masing-masing komoditas setiap harinya.

Pengontrol MPC berusaha untuk mengurangi kerugian yang akan terjadi pada investor ketika harga salah satu komoditas mengalami penurunan. Pada saat bersamaan, pengontrol MPC berusaha untuk memaksimalkan return dari aset ketika terdapat harga komoditas yang mengalami kenaikan. Sebagai hasilnya, total modal yang dimiliki investor pada masing-masing aset mengalami kenaikan sepanjang periode waktu.

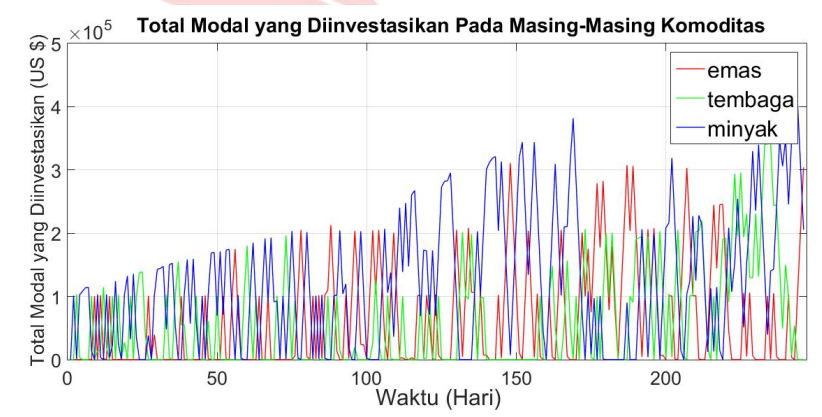

Gambar 2. Jumlah Modal yang Diinvestasikan Pada Masing-Masing Komoditas 


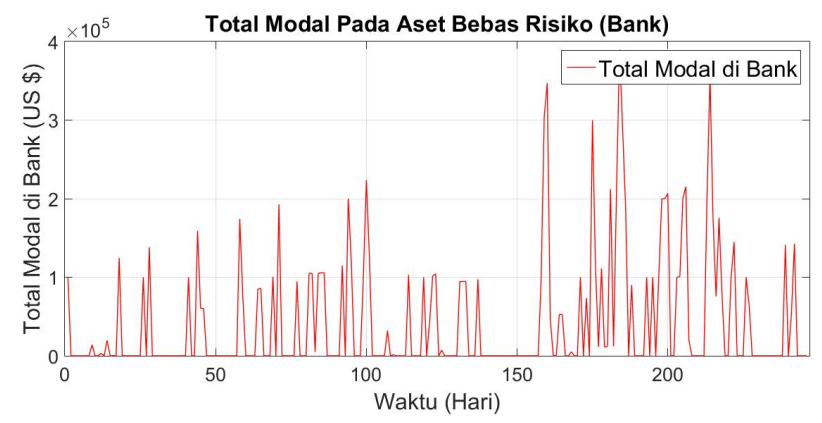

Gambar 3. Perubahan Modal Investor Pada Aset Bebas Risiko

Gambar 3 menunjukkan jumlah modal yang diinvestasikan pada aset bebas risiko (bank) selama periode investasi. Pada 50 hari pertama, tidak terdapat perbedaan yang cukup signifikan pada jumlah modal yang diinvestasikan di bank. Hal ini dipengaruhi oleh batasan jumlah modal awal yang dimiliki oleh investor serta constraints pada variabel kontrol.

Akan tetapi, setelah hari ke-50 dan seterusnya, jumlah moda yang diinvestasikan di bank menunjukkan perubahan yang cukup signifikan hingga hampir mencapai $4 \times 10^{5}$. Jumlah tersebut didapatkan oleh investor dari return jual beli komoditas selama kurun waktu periode investasi.

Berdasarkan Gambar 4, dapat dilihat bahwa modal yang dimiliki oleh investor pada seluruh asetnya mengalami kenaikan. Pada kondisi awal jumlah modal yang dimiliki investor adalah US\$10 $10^{5}$ dan pada kondisi akhir jumlah modal yang dimiliki investor adalah US $\$ 5 \times 10^{5}$. Kenaikan ini terjadi karena jumlah modal yang diinvestasikan pada portofolio komoditas berusaha untuk mencapai reference trajectory yang ditetapkan sebelumnya sebesar $10^{6}$.

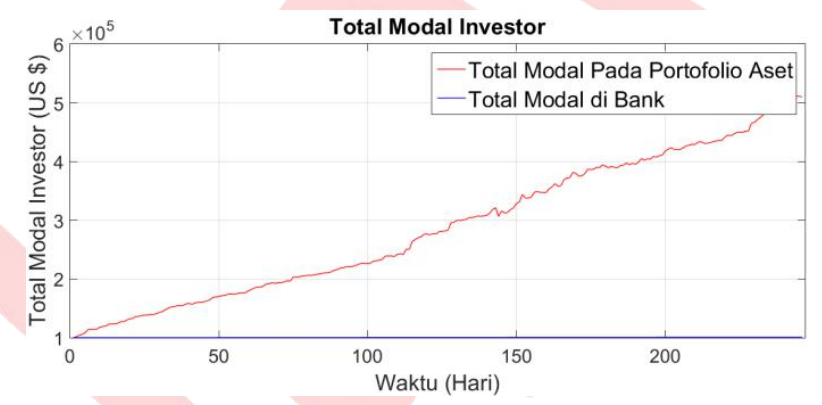

Gambar 4. Perubahan Seluruh Modal yang Dimiliki Oleh Investor

Sebagai perbandingan, apabila investor memutuskan untuk menginvestasikan modalnya pada bank, maka pada akhir periode investasi dia hanya mendapatkan uang sebesar US\$1.0009 $\times 10^{5}$.

Hal lain yang perlu dicatat adalah pada beberapa hari terlihat bahwa modal investor mengalami penurunan, hal ini terjadi karena pada hari tersebut return dari beberapa komoditas bernilai negatif, sehingga investor mengalami kerugian. Akan tetapi, kerugian ini dapat ditutupi oleh keuntungan di beberapa hari berikutnya, sehingga secara keseluruhan jumlah modal investor mengalami kenaikan. 


\section{E. SIMPULAN DAN SARAN}

Pengendali model predictive control (MPC) dapat diterapkan dengan baik pada permasalahan optimasi portofolio komoditas. MPC dapat memberikan nilai kontrol yang optimal dengan adanya kendala pada state dan kontrol pada sistem. Berdasarkan hasil simulasi, terlihat bahwa seluruh nilai kontrol berada pada batasan constraint yang diberikan. Hal penting yang perlu dicatat adalah bahwa nilai return komoditas harian berpengaruh terhadap jumlah modal yang diinvetasikan pada masing-masing komoditas setiap harinya.

Pada kondisi awal jumlah modal yang dimiliki investor adalah US\$ $1 \times 10^{5}$. Pada kondisi akhir jumlah modal yang dimiliki investor pada portofolio komoditas mendekati US\$5 $\times 10^{5}$. Kenaikan ini terjadi karena jumlah modal yang diinvestasikan pada portofolio komoditas berusaha untuk mencapai reference trajectory yang ditetapkan sebelumnya, yaitu $1 \times 10^{6}$. Selain itu, pengontrol MPC juga berusaha untuk mengurangi kerugian yang akan terjadi pada investor ketika harga salah satu komoditas mengalami penurunan.

Secara umum jumlah modal investor pada beberapa hari mengalami penurunan akibat penurunan harga komoditas, sehingga investor mengalami kerugian. Akan tetapi, kerugian ini dapat ditutupi oleh keuntungan di beberapa hari berikutnya, sehingga secara keseluruhan jumlah modal investor tetap naik.

Adapun saran yang penulis berikan untuk penelitian berikutnya adalah penulis hanya mempertimbangkan kendala yang terdapat pada transfer dana dari dan ke dalam aset bebas risiko, transfer dana dari dan ke rekening pinjaman, jumlah maksimum dana pinjaman, serta jumlah minimum dana di aset komoditas dan bank. Pada penelitian berikutnya dapat dipertimbangkan penambahan kendala Value at Risk (VaR) pada sistem manajemen portofolio komoditas. Tujuannya adalah mempertimbangkan pengukuran risiko investasi dalam pembentukan portofolio komoditas.

Pada penelitian ini, penulis menggunakan data return komoditas harian dari ketiga perusahaan sebagai salah satu variabel pembentuk matriks ruang keadaan. Pada penelitian selanjutnya dapat digunakan metode estimasi untuk menghitung nilai komoditas harian dan return komoditas harian sehingga diperoleh matriks persamaan ruang keadaan hasil estimasi yang selanjutnya dapat digabungkan dengan metode optimasi untuk mendapatkan portofolio komoditas yang optimal.

\section{REFERENSI}

Alba, C.B., and Camacho, E.F. (2013) Model Predictive Control. London: Springer Science \& Business Media.

Bodie, Z., Kane, A., and Marcus, A. J. (2015). Portfolio management. New York: McGraw Hill/Learning Solutions

Chandra, P. (2017). Investment analysis and portfolio management. Chennai: McGraw-hill education.

Darmadji, T., and Fakhruddin, H.M. (2011). Pasar Modal di Indonesia (Third Edition). Jakarta: Salemba Empat.

Dombrovsky,V. and Lashenko,E.A. (2003). Dynamic Model of Active Portfolio Management With Stochastic Volatility in Incomplete Market. SICE 2003 Annual Conference, vol. 1, 516 - 521.

Levine, H. A. (2005). Project portfolio management: a practical guide to selecting projects, managing portfolios, and maximizing benefits. London: John Wiley \& Sons.

Martinsuo, M., and Lehtonen, P. (2007). Role of single-project management in achieving portfolio management efficiency. International journal of project management, 25(1), 56-65.

Muske, K. R., and Rawlings, J. B. (1993). Model predictive control with linear models. AIChE Journal, 39(2), 262-287. 
Qin, S. J., and Badgwell, T. A. (2003). A survey of industrial model predictive control technology. Control engineering practice, 11(7), 733-764.

Seki, H., Ogawa,M., Ooyama,S., Akamatsu,K., Ohshima,M., and Yang, W. (2001). Industrial Application Of Nonlinear Model Predictive Control to Polymerization Reactors. Journal of Control Engineering Practice, vol. 9, 819-828.

Subchan, Syaifudin, W.H., and Asfihani, T. (2014). Ship Heading Control of Corvette Sigma With Disturbance Using Model Predictive Control. Far East Journal of Applied Mathematics, vol. 87, no 3, 245-256.

Wang, L. (2009). Model Predictive Control System Design and Implementation using MATLAB. Melbourne: Springer.

Wang, Y., and Boyd, S. (2009). Fast model predictive control using online optimization. IEEE Transactions on control systems technology, 18(2), 267-278.

Widianto, A. (2017). Sejarah Kinerja IHSG 10 Tahun. Retrieved February 19, 2020, from https://bolasalju.com/artikel/ sejarah- kinerja-ihsg-10-tahun/.

Yuninda, N.H. (2008). Simulasi Pengendalian Kadar Glukosa Penderita Diabetes Mellitus Tipe 1 Berbasis Metode Aktif Set Model Predictive Control (MPC) Dengan Constraints. Master thesis, Prodi Teknik Elektro, Universitas Indonesia, Jakarta. 
94 | Jurnal Varian| Vol. 3, No. 2, April 2020, Hal. 83-94 